\title{
Influence of ohmic heating on the structural and immunoreactive properties of soybean proteins
}

\author{
Ricardo N. Pereira ${ }^{\text {a, }}$, Rui M. Rodrigues ${ }^{a}$, Luís Machado ${ }^{a}$, Sara Ferreira ${ }^{a}$, Joana Costa ${ }^{b}$, \\ Caterina Villa $^{\mathrm{b}}$, Mariana P. Barreiros ${ }^{\mathrm{a}}$, Isabel Mafra ${ }^{\mathrm{b}}$, José A. Teixeira ${ }^{\mathrm{a}}$, António A. Vicente ${ }^{\mathrm{a}}$ \\ ${ }^{a}$ Centre of Biological Engineering, University of Minho, 4710-057, Braga, Portugal \\ ${ }^{\mathrm{b}}$ REQUIMTE-LAQV, Faculty of Pharmacy, University of Porto, 4050-313, Porto, Portugal
}

\section{A R T I C L E I N F O}

\section{Keywords:}

Ohmic heating

Electrical frequency

Electric field

Electrochemical reactions

Immunoreactivity

\begin{abstract}
A B S T R A C T
Ohmic heating $(\mathrm{OH})$ encompasses interesting benefits towards thermal processing. Envisaging an increasing relevance of soybean protein as an alternative non-animal protein, it is important to understand how $\mathrm{OH}$ can contribute to the quality and immunoreactivity of soybean-derived products. This study describes, for the first time, the impact of $\mathrm{OH}$ when applied at different electrical frequencies $(50 \mathrm{~Hz}-20 \mathrm{kHz})$ and moderate electric field intensities (up to $20 \mathrm{~V} / \mathrm{cm}$ ), on the leakage of metals from the electrodes and immunoreactivity aspects of soybean protein isolate (SPI). This was achieved by monitoring the occurrence of electrochemical reactions and evaluating IgG-binding capacity. $\mathrm{OH}$ performed at $50 \mathrm{~Hz}$ and $95{ }^{\circ} \mathrm{C}$ induced significant alterations on the intrinsic fluorescence of SPI $(p \leq 0.05)$ and the release of detectable amounts of $\mathrm{Fe} / \mathrm{Ni}$, with a subsequent reduction of $36 \%$ in the immunoreactivity of Gly $\mathrm{m}$ TI. The occurrence of non-thermal effects, as well as the interaction between protein and trace metals, may result in a partial blockage of protein epitopes, thus impairing specific antibody binding. These findings present novel information about the importance of $\mathrm{OH}$ parameters, such as electrical frequency and occurrence of electrochemical reactions, which can affect the structure and immunoreactivity of SPI fractions.
\end{abstract}

\section{Introduction}

Soybean (Glycine max) is an important source of protein, containing around $40 \%$ of protein on an average dry matter (Chen et al., 2016; Verhoeckx et al., 2015). The two major storage proteins present on soybean protein isolate (SPI) are glycinin (11S globulin, also known as legumin) and $\beta$-conglycinin (7S globulin, also known as vicilin), belonging to the Cupin superfamily of proteins and representing $70 \%$ of the soybean protein fraction (Costa et al., 2020; Rickert et al., 2004; Verhoeckx et al., 2015). These two proteins are classified as soybean allergens, being designated as Gly m 6 and Gly m 5 (WHO/IUIS, 2020), respectively, alongside 17 other allergenic proteins (e.g., Gly m TI) (Allergome, 2020).

Food processing aims at providing a safe and nutritious diet to promote the health of the consumers. In this context, soybean can be processed in several ways before human consumption such as cooking, fermenting, grinding among others (Cabanillas et al., 2018). Thermal processing, in particular, can lead to different structural/sequential modifications of the proteins, such as aggregation phenomena and formation of new molecular bonds, rearrangement of the disulfide bonds, breakdown of peptide bonds and chemical modification of amino acids within the protein structure (Ashaolu, 2020; Wu et al., 2019). As a consequence, such modifications are known to affect some of their allergenic properties (Costa et al., 2020). Novel non-thermal processing methods - such as pulsed ultraviolet light, cold atmospheric pressure plasma, gamma-irradiation and pulsed electric fields - have also shown some promising results in reducing the immunoreactive properties of soybean (Li et al., 2007; Meinlschmidt et al., 2016). Ohmic heating (OH) is an emergent food processing technology that relies on the application of a moderate electric field, typically below $1000 \mathrm{~V} / \mathrm{cm}$, resulting in heat dissipation through the Joule effect (Geada et al., 2018; Pereira et al., 2016; Sastry, 2004). This technology allows a more uniform and efficient heating process, avoiding overheating and the limitations of heating transfer mechanisms (Li et al., 2018; Lu et al., 2015). The heating efficiency of this technology could also reduce the time and energy consumption during the heating process, leading to an increase

\footnotetext{
* Corresponding author.

E-mail address: rpereira@deb.uminho.pt (R.N. Pereira).
} 
in the nutritional value of soybean products. Contrarily to other emergent food processing technologies, there is still a lack of knowledge about how the thermal and non-thermal effects of $\mathrm{OH}$ can contribute to structural and immunoreactivity alterations of food proteins, such as soybean proteins. Recently, it was evidenced that $\mathrm{OH}$ can change the chemical composition and the functional properties of soybean milk - i. e., increases in the free amino groups and reduced foaming ability ( $\mathrm{Li}$ et al., 2018). Regarding bovine milk, it was evidenced that, depending on the heating kinetics, the monomeric and aggregated forms of $\beta$-lactoglobulins (Bos d 5) can be adjusted, leading to different effects on its immunoreactivity (Pereira et al., 2020). However, the role of electric variables such as electric field and frequency towards structural changes and immunological properties of soybean proteins remains undisclosed.

During $\mathrm{OH}$, Faradaic reactions take place at the interfaces between electrode and heating media. This can result in the electrolysis of the solvent or electrode corrosion, originating interactions between metal ion ligands and biological molecules, thus risking the quality and safety of the products (Salari \& Jafari, 2020). Among such issues, the following can occur: i) color changes resulting from the release and incorporation of metal oxides such as iron ( $\mathrm{Fe}$ ) oxides; ii) aggregation or precipitation of proteins mediated by metal ions; and iii) toxicity increase, when the levels of a secondary metal constituent, such as nickel (Ni) or chromium (Cr), are above allowable concentrations for human consumption. When $\mathrm{OH}$ takes place, the occurrence of electrochemical reactions of oxidation and reduction depends on several factors: applied electrical frequency; chemical composition of the medium; electrical conductivity; current density through the system; treatment duration and chemical nature of the electrode surface. However, fundamental studies about the impact of $\mathrm{OH}$ conditions on electrochemical reactions at the electrode-solution interface are still limited. It has been already evidenced that, in contrast to what happens from high frequency $\mathrm{OH}$ (e.g. $20 \mathrm{kHz}$ ), low frequencies of $50 \mathrm{~Hz}$ can significantly increase the flux of metal ions from stainless steel electrodes, promoting electrolysis, material corrosion, and metal-ion leakage to the heating medium along the process (Pataro et al., 2014). Therefore, electrode stability is a fundamental factor in $\mathrm{OH}$. The chosen material must be stable and resistant to electrochemical reactions, when in contact with aqueous media, which occur mostly at low electrical frequency. Conformational changes and electrochemical reactions induced by this technology could affect the allergenic properties of soybean by reducing, enhancing or creating new epitopes, which should be thoroughly investigated.

This work aimed at understanding how $\mathrm{OH}$ could affect the structure and the immunoreactive properties of soybean proteins. For this purpose, $\mathrm{OH}$ processing at different conditions - i.e., frequencies from $50 \mathrm{~Hz}$ to $20 \mathrm{kHz}$ and electric fields from $2 \mathrm{~V} / \mathrm{cm}$ to $20 \mathrm{~V} / \mathrm{cm}$ - was benchmarked against conventional heat exchange treatments, allowing the identification of the conditions inducing major structural changes on protein fractions (glycinin, $\beta$-conglycinin, and trypsin inhibitor) and how they affect their IgG-binding capacity. These findings might contribute to propose new processing protocols for reducing the immunoreactivity and metal contamination of soybean and other vegetable proteins.

\section{Materials and methods}

\subsection{Preparation of protein solution}

Soybean protein isolate (SPI) (lyophilized, protein $\geq 90 \%$; fat $\leq$ $0.5 \%$; ash $\leq 5.8 \%$; moisture $\leq 7 \%$; Induxtra de Suministros Llorella, Banyoles-Spain) solutions were prepared at $1 \mathrm{mg} / \mathrm{mL}$ in distilled water and kept under stirring for $1 \mathrm{~h}$. After rehydration, the protein was subjected to a pH-shift to promote higher solubilization (Jiang et al, 2010, 2018; Yildiz et al., 2017). pH was adjusted to 11 with a sodium hydroxide solution ( $3 \mathrm{~mol} / \mathrm{L}$ ) and, after $1 \mathrm{~h}$ at high $\mathrm{pH}$, it was readjusted to 7 with a hydrochloric acid solution $(3 \mathrm{~mol} / \mathrm{L})$. Finally, the protein solution was heated for $30 \mathrm{~min}$ at $60^{\circ} \mathrm{C}$ in a water bath to ensure maximum solubilization and kept overnight at $4{ }^{\circ} \mathrm{C}$. SPI solution was centrifuged at
$1252 \mathrm{~g}$ for $10 \mathrm{~min}$ and the supernatant was recovered. The solubility efficiency of the SPI during this preparation was determined by UV absorbance at $280 \mathrm{~nm}$ with a UV 96 well-microplate (Synergy HT, BioTek Instruments, Inc., Winooski, VT, U.S.A.). The soybean protein absorbance coefficient at this wavelength has been described to be around 6.04 for protein solution with a concentration of $10 \mathrm{mg} / \mathrm{mL}$ (O'Neill \& Kinsella, 1987). Protein concentration was adjusted by dilution and the solution conductivity was adjusted to $1 \mathrm{mS} / \mathrm{cm}$ with sodium chloride solution $(5 \mathrm{~mol} / \mathrm{L})$. At the end of this procedure, a concentration of $0.5 \mathrm{mg} / \mathrm{mL}$ was obtained, ensuring a constant protein concentration in all the processing conditions.

\subsection{Thermal treatments}

Thermal treatments were performed at $95{ }^{\circ} \mathrm{C}$ for $10 \mathrm{~min}$. The temperature was chosen to be higher than the glycinin (Gly $\mathrm{m} \mathrm{6}$ ) and $\beta$-conglycinin (Gly $\mathrm{m} \mathrm{5}$ ) and soybean trypsin (Gly m TI) inhibitor denaturation temperatures $\left(92{ }^{\circ} \mathrm{C}, 71^{\circ} \mathrm{C}\right.$ and $65^{\circ} \mathrm{C}$, respectively) (Liu et al., 2004; Roychaudhuri et al., 2003). These treatments were performed under $\mathrm{OH}$ and conventional heating (COV), following the same heating kinetics to allow a direct comparison of both methods. A non-heated SPI sample (NH) as used as control.

\subsubsection{Conventional heating (COV)}

$\mathrm{COV}$ was performed using a cylindrical water-jacketed glass reactor vessel (30 mm internal diameter and $100 \mathrm{~mm}$ length) connected to a temperature-controlled circulatory water bath (Julabo HE-4 Seelbach/ Germany). The temperature profile was measured using a type-K thermocouple placed at the geometric center of the sample. Temperature data was registered using a data logger (National Instruments, USB9161, National Instruments Corporation, Austin, TX, USA). Solutions labeled with " $0 \mathrm{~Hz}$ " correspond to the ones subjected to COV (no electric field applied).

\subsubsection{Ohmic heating $(\mathrm{OH})$}

$\mathrm{OH}$ experiments were carried out in the same reactor as described previously (see section 2.2.1), but equipped with two titanium (Ti) electrodes (26 mm diameter) isolated at each edge with polytetrafluoroethylene (PTFE). A digital function generator $(1 \mathrm{~Hz}-25 \mathrm{MHz}$ and 1-10 V; Agilent 33220A, Penang, Malaysia) was used to produce a sinusoidal electric wave of small peak voltage that was then amplified (4505 Precision Power Amplifier; Miko-Kings Instruments Ltd, HongKong, China) and delivered to the SPI solution. The temperature was measured and registered as mentioned in section 2.2.1. The heating temperature was controlled through the adjustment of the electric field applied to produce a heating profile similar to the one of the COV as described elsewhere (Pereira et al., 2016, 2020). The OH experiments were conducted under different frequencies: $50 \mathrm{~Hz}, 500 \mathrm{~Hz}, 2 \mathrm{kHz}$, and $20 \mathrm{kHz}$. The electrode gap was maintained constant at $30 \mathrm{~mm}$ for all the tested conditions and, whenever necessary, the electric field strengths during treatment varied between $2 \mathrm{~V} / \mathrm{cm}$ and $20 \mathrm{~V} / \mathrm{cm}$.

\subsection{Structural characterization}

Characterization of SPI was performed to identify major protein fractions and assess potential structural changes induced by the applied treatments. SPI composition was evaluated by sodium dodecyl sulfate polyacrylamide gel electrophoresis (SDS-PAGE), while structural changes were evaluated by UV measurement, intrinsic fluorescence of the aromatic amino acids (tryptophan, tyrosine and phenylalanine), and extrinsic fluorescence. These spectroscopic measurements provide information on the position of amino acids in the protein and the accessibility of hydrophobic sites, being described in following sections.

\subsubsection{SDS-PAGE}

Electrophoretic analysis was performed with acrylamide/ 
bisacrylamide gels using a Mini Protean Tetra-cell (Bio-Rad Laboratories, Hercules, CA, USA). The gels were prepared at a concentration of $12 \%$ for the resolution gel and $4 \%$ for the stacking gel of acrylamide/ bisacrylamide $(37.5: 1,30 \%)$. For the resolution gel, it was also added a solution of tris(hydroxymethyl)aminomethane- $\mathrm{HCl}$ (Tris- $\mathrm{HCl}$ ) $1.5 \mathrm{~mol} / \mathrm{L}$ at $\mathrm{pH} 8.8$, SDS at $10 \%$, ammonium persulfate (APS) at $10 \%$ and tetramethylethylenediamine (TEMED). For the stacking gel, the same solutions were used as in the resolution gel, replacing tris- $\mathrm{HCl} 1.5 \mathrm{~mol} / \mathrm{L}$ at $\mathrm{pH} 8.8$ with tris- $\mathrm{HCl} 0.5 \mathrm{~mol} / \mathrm{L}$ at $\mathrm{pH}$ 6.8. The running buffer used for the electrophoresis was a stock solution of tris(hydroxymethyl)aminomethane $(0.250 \mathrm{~mol} / \mathrm{L})$, with glycine $(1.920 \mathrm{~mol} / \mathrm{L})$ and SDS $(36 \times 10$

${ }^{-3} \mathrm{~mol} / \mathrm{L}$ ) in distillated water. This buffer was diluted ten times before use. The sample buffer used was $2 \times$ Laemmli Solution (Bio-Rad Laboratories, Inc., Hercules, CA, USA). Each SPI solution (at $0.5 \mathrm{mg} / \mathrm{mL}$ ) was added to the sample buffer in a ratio of $1: 1$ and then loaded into the gel well. The amount of total protein loaded was of $3.8 \mu \mathrm{g}$ for SDS-PAGE. The running conditions applied were $300 \mathrm{~V}$ and $60 \mathrm{~mA}$. Proteins were visualized by staining the gels with a Coomassie Blue R-250 solution.

\subsubsection{UV absorbance determination}

UV measurements were performed at $280 \mathrm{~nm}$ for the untreated and treated samples using a UV 96 well-microplate (Synergy HT, BioTek Instruments, Inc., Winooski, VT, U.S.A.). Results were expressed as relative change of absorbance at $280 \mathrm{~nm}\left(R A_{280} \mathrm{~nm}\right) \mathrm{nm}$ towards untreated samples and calculated according to equation (1):

$R A_{280 \mathrm{~nm}}=\frac{A H_{280 \mathrm{~nm}}-A N H_{208 \mathrm{~nm}}}{A N H_{280 \mathrm{~nm}}} \cdot 100 \%$

where $\mathrm{AH}_{280 \mathrm{~nm}}$ and $\mathrm{ANH}_{280 \mathrm{~nm}}$ correspond to samples heated (either by $\mathrm{OH}$ or $\mathrm{COV}$ ) and non-heated, respectively.

\subsubsection{Fluorescence analysis}

Fluorescence analysis relied on the intrinsic and extrinsic fluorescence measurement of the SPI solution using a fluorimeter from Aqualog (Horiba-Jobin Yvon, Inc. Japan). The intrinsic fluorescence was determined at an excitation wavelength of $280 \mathrm{~nm}$ and the emission was collected from 290 to $500 \mathrm{~nm}$. Extrinsic fluorescence determinations were carried out using 8-anilino-1-naphthalenesulfonic acid (ANS) as a hydrophobic probe with an excitation wavelength of $370 \mathrm{~nm}$ and an emission zone between 390 and $650 \mathrm{~nm}$. The ANS stock solution was prepared in methanol at a final concentration of $1.5 \mathrm{mmol} / \mathrm{L}$ and $100 \mu \mathrm{L}$ were added to $3 \mathrm{~mL}$ of SPI solution for measurement.

\subsection{Inductively coupled plasma mass spectrometry}

The quantification of metal release into ohmic-heated solutions was performed by inductively coupled plasma mass spectrometry (ICP-MS), using an ICP-OES OTIMA 8000 (PerkinElmer, Waltham, USA) with argon plasma and radial viewing mode. Calibration curves were established for each different element at specific wavelengths (i.e. Fe $238.204 \mathrm{~nm}$; Ni - $221.648 \mathrm{~nm}$; $\mathrm{Cr}-283.563 \mathrm{~nm}$ and $\mathrm{Ti}-334.940 \mathrm{~nm}$ ) measuring eight different concentrations of multi-element standards. Sample aliquots of $3 \mathrm{~mL}$ were diluted up to $5 \mathrm{~mL}$ with $2 \%$ nitric acid to stabilize samples. After calibration, the concentration (expressed as $\mu \mathrm{g}$ / L) of the metallic species of interest dissolved in heated and non-heated samples was measured immediately after each set of experiments. To check the quality of the determinations, blanks (deionized ultrapure water) and standard solutions were analyzed at regular intervals alongside samples.

\subsection{Immunoreactivity analysis}

For enzyme linked-immunosorbent assay (ELISA) and immunoblotting analyses, all SPI samples were diluted to $0.05 \mu \mathrm{g} / \mathrm{mL}$ and $0.2 \mathrm{mg}$ / $\mathrm{mL}$, respectively. Protein concentration was assessed by UV spectrophotometry on a Synergy HT multi-mode microplate reader (BioTek Instruments, Inc., Winooski, VT, USA), using a Take3 microvolume plate accessory and the protein 280 protocol in the Gen5 data analysis software version 2.01 (BioTek Instruments, Inc., Winooski, VT, USA).

\subsubsection{Indirect ELISA}

Indirect ELISA was performed in high protein-binding capacity polystyrene 96-well plates (Nunc MaxiSorp ${ }^{\mathrm{TM}}$ flat-bottom, Thermo Scientific, Rochester, NY, USA) to ensure maximal protein coating capacity, thus enabling hydrophobic-ionic binding interactions. ELISA plates were coated for $2 \mathrm{~h}$, at room temperature, with $100 \mu \mathrm{L}$ of SPI solution submitted to different $\mathrm{OH}$ treatments $(0.05 \mu \mathrm{g} / \mathrm{mL})$ and untreated SPI solution that was 4 -fold serially diluted to generate the calibration curve (50-0.0122 $\mu \mathrm{g} / \mathrm{mL}, 7$ concentration levels) in coating buffer ( $\mathrm{pH} 9.6$ ) (10 mmol/L Na $\mathrm{CO}_{3}, 30 \mathrm{mmol} / \mathrm{L} \mathrm{NaHCO} 3$ ). After washing 3-times with $200 \mu \mathrm{L}$ (each) of PBS $0.01 \mathrm{mmol} / \mathrm{L}(0.1 \%$ Tween 20$)$, the plates were blocked for $2 \mathrm{~h}$ at room temperature with $200 \mu \mathrm{L}$ of coating buffer containing $2 \%$ of ficoll-400 (Carl Roth GmbH, Karlsruhe, Germany). Then, the plates were washed again $(3 \times)$ in the same conditions, followed by incubation overnight at $4{ }^{\circ} \mathrm{C}$ with $100 \mu \mathrm{L}$ of soybean antitrypsin inhibitor antibody (Abcam, Cambridge, UK) 40,000-fold diluted in assay buffer (PBS $0.05 \mathrm{mmol} / \mathrm{L}, 0.1 \%$ Tween 20) containing $2 \%$ of ficoll- 400 . A second incubation step was performed after washing the plates $3 \times$ in the same conditions. This second incubation was carried out with $100 \mu \mathrm{L}$ of anti-rabbit IgG peroxidase antibody (Sigma-Aldrich, St Louis, MO, USA) 40,000-fold diluted in assay buffer containing $2 \%$ of ficoll-400 for $1 \mathrm{~h}$ at room temperature, which was then followed by the final 3 washes (in the same conditions). Product formation was visualized with the addition of $50 \mu \mathrm{L}$ of 3,3',5,5'-tetramethylbenzidine liquid substrate (Sigma-Aldrich, St Louis, MO, USA) by the appearance of a blue color after incubating the plate for 5-10 min in the dark. The reaction was stopped by adding $50 \mu \mathrm{L}$ of sulphuric acid $(2 \mathrm{~mol} / \mathrm{L})$, resulting in the development of a yellow color in the wells.

The ELISA plates were read at $450 \mathrm{~nm}$ in a plate reader (SPECTROstar Nano, BMG Labtech, Ortenberg, Germany) and the absorbance data was evaluated with MARS data analysis software (BMG Labtech, Ortenberg, Germany). Data analysis included the application of a 4parametric logistic function using the absorbance values measured at $450 \mathrm{~nm}$ as a function of the logarithmic concentration of the SPI calibration standards, according to equation (2):

$\mathrm{Y}=\frac{\mathrm{A}-\mathrm{D}}{1+\left(\frac{\mathrm{X}}{\mathrm{C}}\right)^{\mathrm{b}}}+\mathrm{D}$

where $\mathrm{Y}$ is the optical density (absorbance), $\mathrm{A}$ is the maximum absorbance, $\mathrm{b}$ is the slope of the calibration curve in the linear range, $\mathrm{C}$ is the $50 \%$ inhibition-concentration - IC50 $(\mu \mathrm{g} / \mathrm{L})$, D is the minimum absorbance, and $\mathrm{X}$ is the analyte concentration ( $\mu \mathrm{g} / \mathrm{L})$. Each SPI processing treatment was analyzed in $n=3$ replicates and repeated in 5 independent assays, totalizing $n=15$ determinations per treatment. The effect that each treatment had on the immunoreactivity of soybean trypsin inhibitor (Gly $\mathrm{m} \mathrm{TI}$ ) was further calculated by comparison with $\mathrm{NH}$ (control) sample and expressed as a percentage of Gly $\mathrm{m}$ TI reactivity.

\subsubsection{Native-PAGE and immunoblotting analysis}

Native-PAGE (5-12\%) gels were home-made, using a discontinuous system as described in section 2.3.1. For native conditions, Native Sample Buffer (Bio-Rad Laboratories, Inc., Hercules, CA, USA) was mixed in a 1:1 ratio with each SPI treatment, followed by direct application on native-PAGE gels. The amount of total protein loaded was $1 \mu \mathrm{g}$ for native-PAGE gels and blots. Electrophoresis was carried out in MiniPROTEAN ${ }^{\circledR}$ Tetra System (Bio-Rad Laboratories, Inc., Hercules, CA, USA), at $150 \mathrm{~V}$ with $1 \times$ Tris/Glycine (Bio-Rad Laboratories, Inc., Hercules, CA, USA) electrophoresis buffer. The gels were stained with Coomassie Brilliant Blue G-250 solution or blotted into a nitrocellulose 
membrane for further analysis. Proteins were visualized using a white tray and gel images were recorded and analyzed with Image Lab 5.2.1 software (Gel Doc ${ }^{\mathrm{TM}}$ EZ Imager, Bio-Rad Laboratories, Inc., Hercules, CA, USA). Precision Plus Protein ${ }^{\mathrm{TM}}$ Dual Color Standards (10-250 kDa, Bio-Rad Laboratories, Inc., Hercules, CA, USA) were used as protein molecular weight marker in gels and blotting membranes.

For the immunoblotting analysis, the native gels were blotted into nitrocellulose membranes $0.2 \mu \mathrm{m}$ transfer pack (Bio-Rad Laboratories, Inc., Hercules, CA, USA), using the Trans-Blot ${ }^{\circledR}$ Turbo $^{\mathrm{TM}}$ Transfer System (Bio-Rad, Laboratories, Inc., Hercules, CA, USA) with automatic turbo protocol ( $2.5 \mathrm{~A}$, up to $25 \mathrm{~V}$ for $10 \mathrm{~min}$ ). After protein transfer, the membranes were washed 3 -times (10 min each) with TBST $1 \times$ (TBS $0.01 \mathrm{~mol} / \mathrm{L}, 0.1 \%$ Tween 20 ) and blocked with TBST $1 \times$ containing $2 \%$ of ficoll-400 for $1 \mathrm{~h}$ at room temperature, with constant and gentle agitation. Following the blockage step, the nitrocellulose membranes were washed 3 -times (10 min each) with TBST $1 \times$ and incubated overnight at $4{ }^{\circ} \mathrm{C}$ with soybean anti-trypsin inhibitor antibody (Abcam, Cambridge, UK) 40,000-fold diluted in incubation buffer (TBST $1 \times$ with $2 \%$ of ficoll-400). After incubating the primary antibody, the membranes were further washed 3-times, as previously described, and incubated for $1 \mathrm{~h}$ at room temperature with secondary antibody antirabbit IgG peroxidase (Sigma-Aldrich, St Louis, MO, USA) 40,000-fold diluted in TBST $1 \times$ with $2 \%$ ficoll- 400 . Then, membranes were washed again 3-times (in the same conditions) to ensure the elimination of unbounded antibody and revealed with Clarity ${ }^{\mathrm{TM}}$ Western ECL (BioRad Laboratories, Hercules, CA, USA) for 2-3 min. Chemiluminescence and colorimetric images were recorded on ChemiDoc Imaging System (Bio-Rad Laboratories, Hercules, CA, USA) and processed with the Image Lab 5.2.1 software (Bio-Rad Laboratories, Inc., Hercules, CA, USA).

\subsection{Statistical analysis}

Statistical analyses involving experimental data were performed using Origin(Pro) (version 9.3, 2016) from OriginLab Corporation, Northampton, MA, USA. Statistical significance within different treatments was determined by ANOVA using the Levene test for variance homogeneity and Tukey's for multiple comparisons using a $p$ value of 0.05 . Unless otherwise stated, all treatments were repeated at least three times using a different batch of samples.

\section{Results and discussion}

Glycinin and $\beta$-conglycinin, represent the major fractions of SPI, whose denaturation is known to occur between 74 and $79{ }^{\circ} \mathrm{C}$ and 90-98 ${ }^{\circ} \mathrm{C}$, respectively (Roychaudhuri et al., 2003; Sobral et al., 2010). Heating binomials below $100{ }^{\circ} \mathrm{C}$ are commonly employed with the purpose of pasteurization, which often results in the denaturation of these SPI fractions, prompting changes of structural, technological, and functional properties - i.e., aggregation, solubility, emulsion and gelation, among others (Wang et al., 2020).

\subsection{SPI composition}

SDS-PAGE in non-denaturing conditions was performed to examine the different SPI fractions before and after performed treatments, as illustrated in Fig. 1. Data show similar electrophoretic pattern, suggesting that such approach was not able to differentiate applied treatments. The fraction of molecular weight of approximately $40 \mathrm{kDa}$ corresponds to the acidic polypeptide (legumin - 11S A3), while the 15$\mathrm{kDa}$ fraction (matches the 11S basic) polypeptide, both composing one subunit of legumins (hexameric structure of $360 \mathrm{kDa}$ ). Different subunits of vicilins (trimeric structures of $150-190 \mathrm{kDa}$ ) $-\beta, \alpha$ and $\alpha$ '- were also identified with associated molecular weights between 50 and $100 \mathrm{kDa}$. These results are in accordance with published literature regarding SPI and soybean derived products (Hsia et al., 2016; Liu et al., 2017).

\subsection{Conformational changes}

Protein content, as well as conformational changes imposed by ligand interactions, $\mathrm{pH}$ shifts and thermal treatments, can be easily detected through UV absorption of amino acid's such as tryptophan and tyrosine (Biter et al., 2019). Fig. 2 shows the effects of $\mathrm{OH}$ (expressed in the relative change of absorbance at $280 \mathrm{~nm}$ ) applied at $10 \mathrm{~V} / \mathrm{cm}$ but with variable electric frequency (where a conventional heating treatment at $95{ }^{\circ} \mathrm{C}$ is represented by $0 \mathrm{~Hz}$ ). Frequencies of $50 \mathrm{~Hz}$ and $500 \mathrm{~Hz}$ resulted in significant changes $(p<0.05)$ on the intensity of measured UV absorbance, with increases of $12 \%$ and $6 \%$, respectively, towards the $\mathrm{NH}$ sample. Knowing that all treatments contain the same protein concentration, this indicates that low electric frequencies $(<500 \mathrm{~Hz})$ have possibly affected the local chemical environment or binding reactions

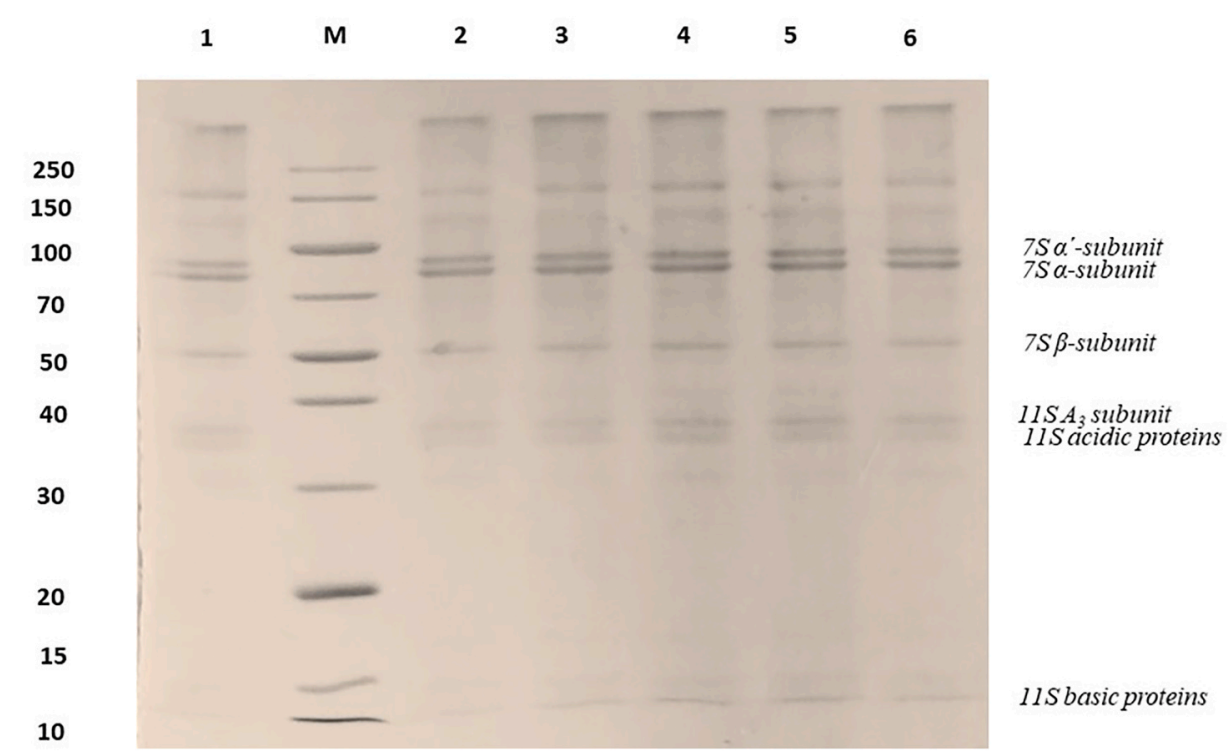

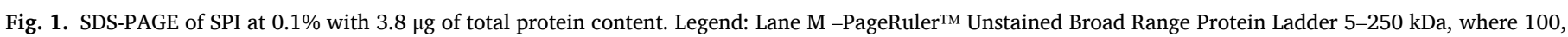

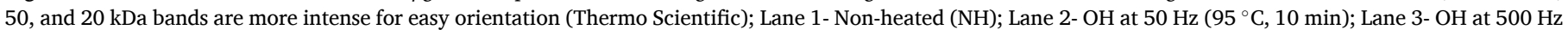
$\left(95^{\circ} \mathrm{C}, 10 \mathrm{~min}\right)$; Lane $4-\mathrm{OH}$ at $2000 \mathrm{~Hz}\left(95^{\circ} \mathrm{C}, 10 \mathrm{~min}\right)$; Lane $5-\mathrm{OH}$ at $20,000 \mathrm{~Hz}\left(95^{\circ} \mathrm{C}, 10 \mathrm{~min}\right)$; and Lane $6-\mathrm{Conventional} \mathrm{heating}\left(\mathrm{COV}, 95^{\circ} \mathrm{C}\right.$, $\left.10 \mathrm{~min}\right)$. 


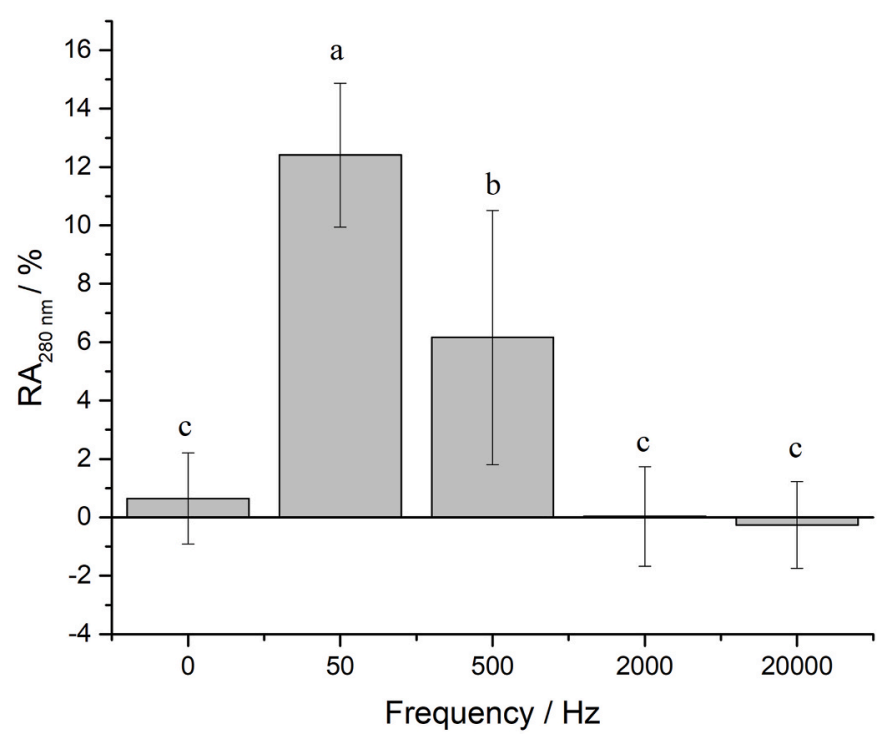

Fig. 2. Effects of electric frequency on relative increase of absorbance at 280 $\mathrm{nm}$ compared with untreated sample. Different letters indicate that difference of the means is significant at level of 0.05 .

because of conformational disturbances, intra and intermolecular interactions, as well as the presence of metals leaked from electrode's, thus changing the UV optical characteristics of treated SPI (Schmid, 2001). To disclose the effect promoted by the intensity of the electric field, treatments of 2 and $20 \mathrm{~V} / \mathrm{cm}$ were also performed at constant electrical frequency - either of $50 \mathrm{~Hz}$ or $20 \mathrm{kHz}$ - but no significant changes ( $p>$ 0.05 ) were observed within the different levels of the electric field intensity applied.

Fluorescence spectroscopy analysis of proteins is considered a powerful non-invasive tool to assess the structural information linked with local molecular polar or apolar environments of the fluorophore (Zhang et al., 2018). Given these marked differences as a result of $\mathrm{OH}$ treatments performed at frequencies of $50 \mathrm{~Hz}$ and $500 \mathrm{~Hz}$, the intrinsic fluorescence and surface hydrophobicity (extrinsic fluorescence using ANS as a fluorescent probe) of all treatments were evaluated to disclose protein conformational shifts affecting tryptophan/tyrosine/phenylalanine residues and the exposure of hydrophobic patches. An example of emission spectra of SPI samples between 290 and $500 \mathrm{~nm}$ (intrinsic fluorescence) and from 390 to $650 \mathrm{~nm}$ (extrinsic fluorescence) is illustrated in Fig. $3 \mathrm{~A}$ and $\mathrm{B}$, respectively. Interestingly, and as observed for UV absorption, the $\mathrm{OH}$ at $50 \mathrm{~Hz}$ were the ones that mostly affect the intrinsic fluorescence, being immediately followed by treatments at $500 \mathrm{~Hz}$. Table 1 resumes maximum emission intensities and corresponding wavelengths for each treatment condition. All SPI treatments presented a maximum emission around $332 \mathrm{~nm}$, showing that the aromatic residues were in an apolar environment, being in accordance with previous studies in which this wavelength ranged from 331 to 342 nm (Deng et al., 2017; Huang et al., 2020).

Results also evidenced the absence of any kind of shift against $\mathrm{NH}$ sample, showing that the polarity of the molecular environment remains unchanged independently of the treatment and electrical frequency applied. $\mathrm{OH}$ at low frequencies of $50 \mathrm{~Hz}$ and $500 \mathrm{~Hz}$ resulted in a significant decrease of maximum intensity $(p<0.05)$ in comparison to $\mathrm{NH}$ SPI. Decreasing the electrical frequency of the $\mathrm{OH}$ caused a marked tendency of maximum emission intensity reduction; $\mathrm{OH}$ at $50 \mathrm{~Hz}$ resulted in a decrease of maximum intensity of $27 \%, 21 \%$ and $23 \%$ when compared with $\mathrm{NH}, \mathrm{COV}(0 \mathrm{~Hz})$ and $\mathrm{OH}$ at $20 \mathrm{kHz}$, respectively, with statistical relevance $(p \leq 0.05)$ (Fig. 3). In opposition, no significant differences $(p>0.05$ ) were observed between $\mathrm{OH}$ at $2 \mathrm{kHz}$ or $20 \mathrm{kHz}$ when compared to $\mathrm{NH}$. This reduction in intrinsic fluorescence along with the absence of peak shifts (no changes in the environment' polarity

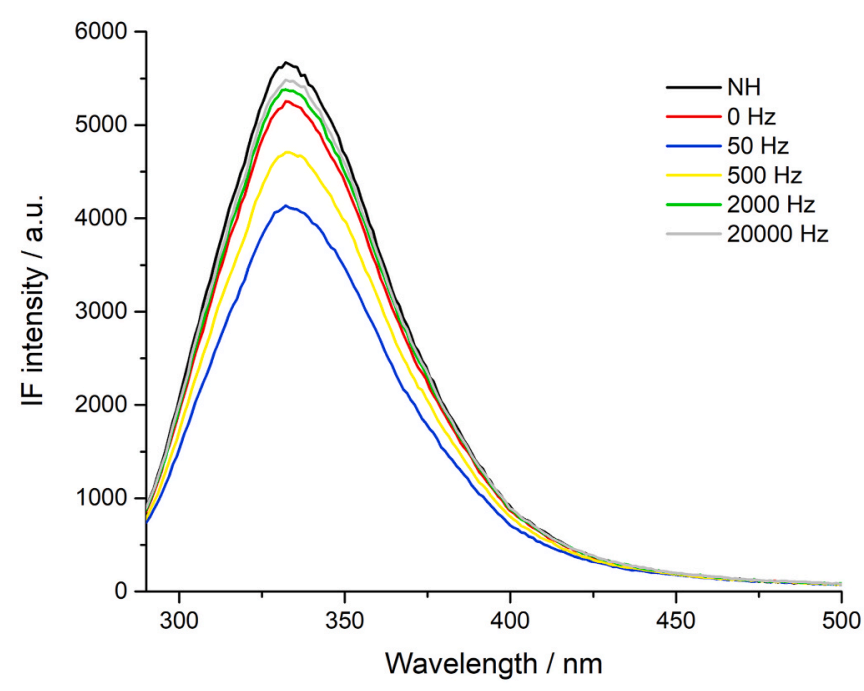

B

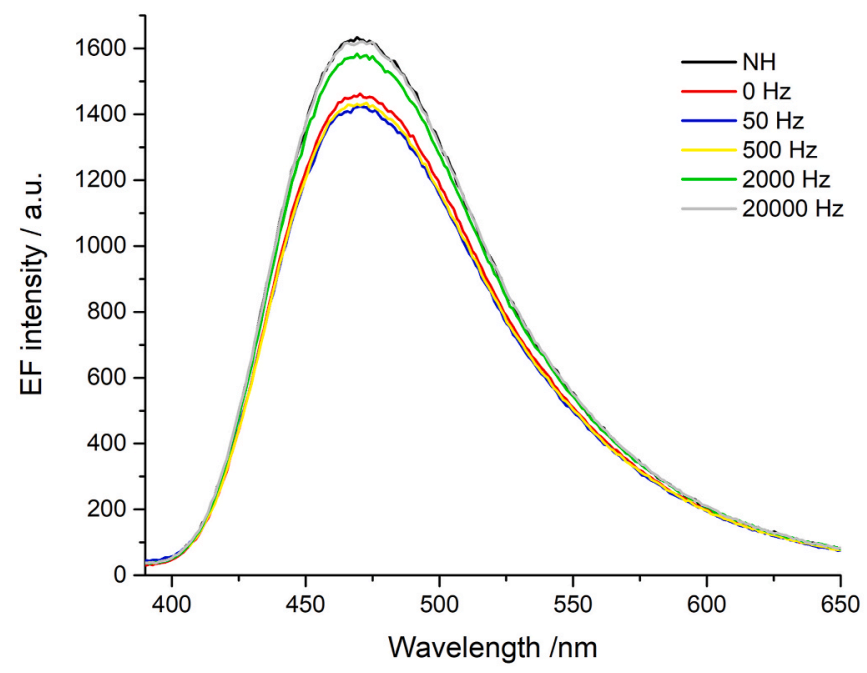

Fig. 3. Intrinsic (A) and extrinsic (B) fluorescence spectra of non-heated, conventional heated $(0 \mathrm{~Hz}$ ) and $\mathrm{OH}($ from $50 \mathrm{~Hz}$ to $20,000 \mathrm{~Hz}$ ) protein samples.

of the fluorophores) implies that the frequencies between 50 and $500 \mathrm{~Hz}$ led to structural rearrangements of the protein fold, resulting in the fluorescence quenching of the aromatic residues (Peng \& Callender, 2018). Extrinsic fluorescence presented a maximum emission intensity ranging from 469 to $472 \mathrm{~nm}$, which is comparable with published literature (Zhang et al., 2018). However, in this case, the ANS probe affinity remained identical among all treatments $(p>0.05)$, indicating that the exposition of hydrophobic pockets appears to be less dependent on the $\mathrm{OH}$ electrical frequency applied. These results are somehow aligned with previous observations regarding the electric frequency effects on bovine $\beta$-lactoglobulin treated at $90{ }^{\circ} \mathrm{C}$ (Rodrigues et al., 2020). The observed quenching effect, particularly at $50 \mathrm{~Hz}$, does not seem to be a consequence of the molecular unfolding of the soybean proteins; otherwise, the exposure of the aromatic amino acids (phenylalanine, tyrosine and tryptophan) to the polar environment (red-shift effect) would be noticed. Additionally, extensive protein denaturation would result in destabilization of protein tertiary structure and increased accessibility to hydrophobic patches (expressed on the increase of extrinsic fluorescence). Several studies have shown that heating vicilins and legumins above denaturation temperatures (from 70 to $85{ }^{\circ} \mathrm{C}$ ) causes significant increases in the hydrophobic interactions (Monteiro \& 
Table 1

Emission intensities of intrinsic and extrinsic fluorescence and corresponding wavelength at maximum intensity.

\begin{tabular}{|c|c|c|c|c|}
\hline \multirow[b]{2}{*}{ Samples } & \multicolumn{2}{|l|}{ Intrinsic fluorescence (IF) } & \multicolumn{2}{|l|}{ Extrinsic fluorescence (EF) } \\
\hline & Maximum intensity/a.u. & Wavelength at max. intensity/nm & Maximum intensity/a.u. & Wavelength at max. intensity/nm \\
\hline Non-heated & $5669.9 \pm 291.2^{\mathrm{a}}$ & $331.4 \pm 1.3^{\mathrm{a}}$ & $1633.5 \pm 325.2^{\mathrm{a}}$ & $468.5 \pm 1.3^{\mathrm{a}}$ \\
\hline $\mathbf{0} \mathrm{Hz}^{\mathrm{a}}$ & $5252.1 \pm 277.7^{\mathrm{a}, \mathrm{b}}$ & $332.6 \pm 0.6^{\mathrm{a}}$ & $1509.5 \pm 217.2^{\mathrm{a}}$ & $471.6 \pm 0.7^{\mathrm{a}}$ \\
\hline $50 \mathrm{~Hz}$ & $4136.9 \pm 205.9^{c}$ & $332.6 \pm 0.6^{\mathrm{a}}$ & $1466.0 \pm 188.6^{\mathrm{a}}$ & $471.6 \pm 2.7^{\mathrm{a}}$ \\
\hline $500 \mathrm{~Hz}$ & $4706.1 \pm 460.6^{\mathrm{b}, \mathrm{c}}$ & $332.6 \pm 2.3^{\mathrm{a}}$ & $1603.7 \pm 290.1^{\mathrm{a}}$ & $471.8 \pm 2.8^{\mathrm{a}}$ \\
\hline $2000 \mathrm{~Hz}$ & $5378.7 \pm 230.2^{\mathrm{a}}$ & $332.6 \pm 1.7^{\mathrm{a}}$ & $1707.3 \pm 243.3^{\mathrm{a}}$ & $471.1 \pm 2.4^{\mathrm{a}}$ \\
\hline $20,000 \mathrm{~Hz}$ & $5486.0 \pm 251.2^{\mathrm{a}}$ & $331.1 \pm 0.9^{\mathrm{a}}$ & $1739.5 \pm 254.8^{\mathrm{a}}$ & $469.0 \pm 4.4^{\mathrm{a}}$ \\
\hline
\end{tabular}

For each column, different letters mean significantly different values ( $\mathrm{p} \leq 0.05)$.

${ }^{\text {a }}$ Corresponds to conventional heating sample.

Lopes-da-Silva, 2019), a fact that was not verified in this study. However, it is important to highlight that the supposed occurrence of intermolecular interactions between denatured proteins may have contributed to a lower number of available hydrophobic sites to bind the ANS (Zhang et al., 2005). This fact explains the less defined pattern for ANS binding measurements, despite the marked reduction tendency of the fluorescence intensity being observed with the decreasing of the electric frequency applied.

To gather more insights about the influence of $\mathrm{OH}$ on the structural properties of SPI, electric frequencies of $50 \mathrm{~Hz}$ and 20,000 Hz were selected for further analysis given their contrasting behavior. Fig. 4 shows the influence of different electric fields applied during $\mathrm{OH}$, namely - i.e. $0 \mathrm{~V} / \mathrm{cm}$ (conventional heating), $2 \mathrm{~V} / \mathrm{cm}, 10 \mathrm{~V} / \mathrm{cm}$ and $20 \mathrm{~V} /$ $\mathrm{cm}$. Contrarily to what has been observed for UV absorption analysis, electric field intensity influenced intrinsic fluorescence. At $50 \mathrm{~Hz}$, when the electric field is increased from $2 \mathrm{~V} / \mathrm{cm}$ to $10 \mathrm{~V} / \mathrm{cm}$ significant differences were observed against $\mathrm{COV}$ (or $0 \mathrm{~V} / \mathrm{cm}$ ), while an increase from 10 to $20 \mathrm{~V} / \mathrm{cm}$ did not bring any significant additional effects $(p>0.05)$. This indicates that a quenching effect is only noticed when a certain threshold in relation to the electric field value is exceeded. Regarding treatments at $20 \mathrm{kHz}$, with the increase of the electric field, no trend was observed in intrinsic fluorescence results, as well as its changes were less expressive. Nonetheless, significant increases in fluorescence intensity $(p \leq 0.05)$ were noticeable when comparing treatments at $2 \mathrm{~V} / \mathrm{cm}$ and $20 \mathrm{~V} / \mathrm{cm}$ with COV.

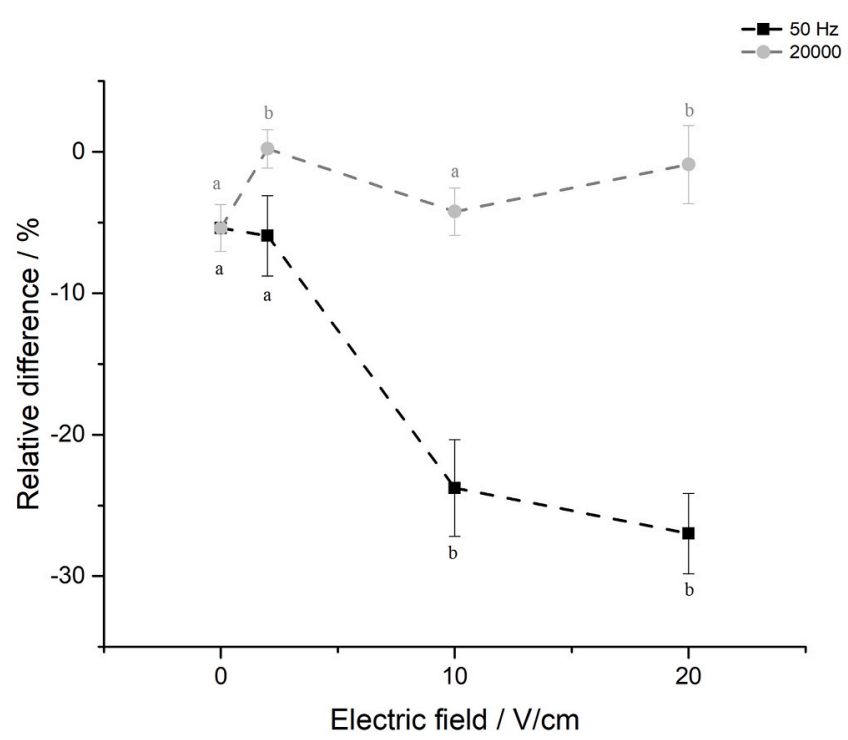

Fig. 4. Influence of electric field intensity on relative difference of maximum intrinsic fluorescence intensity $\left(\mathrm{R}_{\mathrm{IF}}\right)$. Different letters for each frequency condition indicate that difference of the means is significant at level of 0.05 .

\subsection{ICP-MS and electrochemical reactions}

In the present study, titanium electrodes were used, given this metal has high electrochemical resistance. However, trace metals and other components used (for instance, thermocouples or measurement probes, which are usually constructed in stainless steel) are in contact with the heating solution and present lower stability. For these reasons, the quantification of metal release to the protein solutions focused, not only on titanium, but also on some of the main constituents of stainless steel: $\mathrm{Fe}, \mathrm{Ni}$ and $\mathrm{Cr}$. Table 2 shows the concentration of different metals determined by ICP-MS. OH even at $20 \mathrm{kHz}$ result in detectable concentrations of $\mathrm{Fe}$ and $\mathrm{Ti}$. However, when the frequency is lowered to 50 $\mathrm{Hz}$, the total concentration of metals is about 30-times higher, with major contribution of $\mathrm{Fe}$ and $\mathrm{Ni}$, representing $62 \%$ and $30 \%$ of the total, respectively. Besides, $\mathrm{Cr}$ is only present in $\mathrm{OH}$ treated solutions at $50 \mathrm{~Hz}$. In accordance with the Council Directive 98/83/EC (from November 3, 1998) on the quality of water intended for human consumption, the maximum allowable parametric values for $\mathrm{Fe}, \mathrm{Ni}$ and $\mathrm{Cr}$ are $200 \mu \mathrm{g} / \mathrm{L}$, $20 \mu \mathrm{g} / \mathrm{L}$ and $50 \mu \mathrm{g} / \mathrm{L}$, respectively. This directive omits limit values for titanium, which are rarely found. It has been suggested that the maximum allowable concentration of titanium in drinking water should be around $100 \mu \mathrm{g} / \mathrm{L}$, which is supported by chronic toxicity results evidencing a maximum non-effective concentration in rats of $1.08 \mathrm{mg} / \mathrm{L}$ (Dong et al., 1993). It is important to highlight that, even at low-frequency $\mathrm{OH}$, the detected metal concentration was below the legislation limits. However, when the same heating conditions were applied using stainless steel, the values for $\mathrm{Fe}, \mathrm{Ni}$ and $\mathrm{Cr}$ were 8, 2 and 13-times higher, respectively (results not shown), than the ones found in titanium, thus corroborating previous studies (Pataro et al., 2014).

Contrarily to $\mathrm{Fe}$, Ti released to the solution did not seem to be affected by the electrical frequency applied, since no significant differences in the concentration of this metal were found in treatments performed at $50 \mathrm{~Hz}$ and $20 \mathrm{kHz}(p>0.05)$. This fact shows the importance of choosing electrochemical inert materials and appropriate electrical conditions (electric field and frequency).

These results may corroborate the hypothesis that released metals may have worked as quenching agents of tryptophan and tyrosine residues, thus justifying the results observed for the intrinsic fluorescence

Table 2

Quantification of $\mathrm{Fe}, \mathrm{Ni}, \mathrm{Cr}$ and $\mathrm{Ti}$ on the protein's solutions (untreated, conventional heating and ohmic heating at $20,000 \mathrm{~Hz}$ and $50 \mathrm{~Hz}$.

\begin{tabular}{|c|c|c|c|c|}
\hline \multicolumn{5}{|c|}{ Metal concentration $(\mu \mathrm{g} / \mathrm{L})$} \\
\hline & $\mathrm{Fe}$ & $\mathrm{Ni}$ & $\mathrm{Cr}$ & $\mathrm{Ti}$ \\
\hline $\begin{array}{l}\text { Non- } \\
\text { heated }\end{array}$ & N.D. & N.D. & N.D. & N.D. \\
\hline $0 \mathrm{~Hz}^{\mathrm{a}}$ & $0.62 \pm 0.38^{\mathrm{a}}$ & $2.34 \pm 2.39^{\mathrm{a}}$ & N.D. & $0.69 \pm 0.18^{\mathrm{a}}$ \\
\hline $50 \mathrm{~Hz}$ & $190.82 \pm 4.61^{\mathrm{c}}$ & $97.85 \pm 28.03_{b}$ & $17.48 \pm 1,98$ & $4.79 \pm 0.23^{\mathrm{b}}$ \\
\hline $20,000 \mathrm{~Hz}$ & $5.97 \pm 1.02^{\mathrm{b}}$ & N.D. & N.D. & $5.70 \pm 0.79^{\mathrm{b}}$ \\
\hline
\end{tabular}

For each column, different letters mean significantly different values $(\mathrm{p} \leq 0.05)$. N.D. means not detected.

${ }^{\text {a }}$ Corresponds to conventional heating sample. 
of $\mathrm{OH}$ at $50 \mathrm{~Hz}$. Fluorescence quenching seems to be proportionally linked to the power level, increased electric field and decreased electrical frequency (Assiry et al., 2006), which are the two factors that contribute to the promotion of electrochemical reactions. This can be supported by the fact that at higher electrical frequency levels (i.e., 20 $\mathrm{kHz}$ ), or without the presence of an electric field (conventional heating, $0 \mathrm{~Hz}$ ), the metal release was minimum, and no significant differences ( $p$ $>0.05$ ) were noticed on the UV absorption and intrinsic fluorescence when compared to NH sample. Recently, it has been shown that the total amount of released metals (such as $\mathrm{Fe}, \mathrm{Cr}$, and $\mathrm{Ni}$ ) can be enhanced by the presence of globular proteins, such as the ones from whey, which can result in protein aggregation or even precipitation due to complexation mechanisms (Atapour et al., 2019, 2020). For example, iron has a strong ability to interact with fractions from whey protein isolate and it has been used to induce the development of gel structures in pre-heated protein solutions, using conventional thermal treatment and $\mathrm{OH}$ through a process known as "cold-gelation", where the gel microstructure (appearance of filamentous or random aggregate particles) is dependent on the iron/protein ratios (Pereira et al., 2017; Remondetto et al., 2002). Regarding SPI, there is limited information about the interaction of proteins with metal ions, although there is an evidence that metal chlorides can interact with the carboxyl groups of soybean proteins, playing an important role in tofu formation (Arii \& Takenaka, 2014). As first described by Porath et al. (1975), the affinity between metal ions (e.g. iron) and amino acids can be used in chromatography i.e. immobilized metal ion affinity chromatography (IMAC) - to separate protein possessing specific residues, being able to chelate metals. This technique was also used to purify peptides from soybean based on their amino acid composition and affinity to bind $\mathrm{Fe}^{3+}$ (Liu et al., 2012).

\subsection{Effect of ohmic treatment on the immunoreactivity of Gly $m$ TI}

The allergenic soybean trypsin inhibitor protein (STI), also known as Gly $\mathrm{m}$ TI, was selected as the target allergen based on the remarkable stability of this protein towards heat and acid treatments, because of its capacity to return its native structure upon severe heat $\left(95{ }^{\circ} \mathrm{C}\right.$ ) (Roychaudhuri et al., 2003, 2004). These characteristics make Gly m TI a perfect candidate to evaluate the impact of different $\mathrm{OH}$ conditions on the IgG-binding capacity (immunoreactivity) of soybean as an allergenic food. Therefore, an indirect ELISA targeting Gly $\mathrm{m}$ TI was specifically designed to ensure high specificity and sensitivity, focusing on reducing the time per analysis and the problems associated with antibody conjugation (e.g. sandwich ELISA format) (Pereira et al., 2020). Antibody specificity was previously evaluated against different plant species, being specific for the $21 \mathrm{kDa}$ soybean trypsin inhibitor (Gly $\mathrm{m} \mathrm{TI}$ ) (Quirce et al., 2002; Villa et al., 2020). Gly m TI has a globular monomeric structure composed of 1 polypeptide chain with 2 disulfide bonds
(Fig. 5A and B). This protein is constituted of 12 antiparallel beta-strands separated by irregular loops, with six of those forming an antiparallel beta-barrel (De Meester et al., 1998) The barrel is capped on the top by the other six strands, which are symmetrically organized in three pairs around the barrel axis. The Gly $\mathrm{m}$ TI can be expressed in three genetically distinct variants (A, B, and C), that are inherited as codominant alleles (De Meester et al., 1998).

Fig. 6 shows that all treatments seem to contribute to at least $20 \%$ of inhibition in the immunoreactivity of Gly $\mathrm{m}$ TI, which suggests that thermal processing at the conditions studied $\left(95^{\circ} \mathrm{C}\right.$ for $\left.10 \mathrm{~min}\right)$ can by itself reduce the immunoreactivity of SPI. Inhibitory effects promoted by $\mathrm{OH}$ are significantly greater at $50 \mathrm{~Hz}$ and $20 \mathrm{kHz}$ than the ones observed with $\mathrm{COV}(0 \mathrm{~Hz})(p \leq 0.05)$. The highest inhibitory effect seems to be promoted by the $\mathrm{OH}$ treatment at $50 \mathrm{~Hz}$, leading to an approximately $36 \%$ of reduction in the IgG-binding capacity of Gly $\mathrm{m}$ TI when compared to NH sample (Fig. 6). The immunoreactivity of Gly m TI was also assessed by immunoblotting (Fig. 7), which enabled the visual confirmation of the data retrieved from ELISA.

All untreated and treated SPI samples, present a band at approximately $21 \mathrm{kDa}$, which confirms the presence of Gly m TI (Fig. 7). The bands with approximately $12-15 \mathrm{kDa}$ might correspond to chains from distinct genetic variants (co-expressed by different alleles) (Fig. 5). The

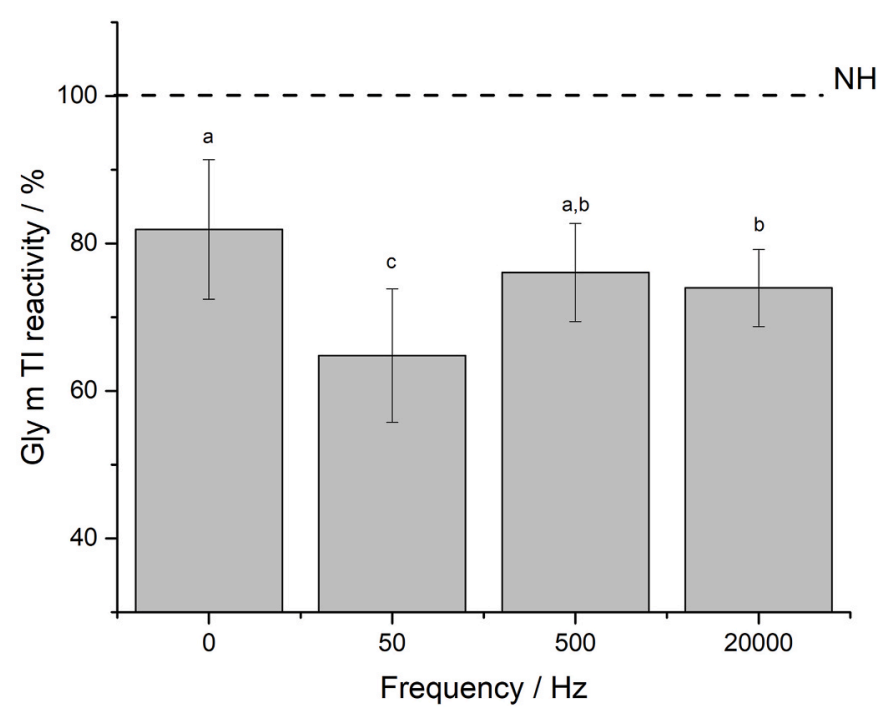

Fig. 6. Effect of ohmic treatment on the immunoreactivity of Gly m TI (soybean trypsin inhibitor) expressed as \% of Gly m TI reactivity with specific antisoybean trypsin inhibitor antibody, assessed by indirect ELISA, normalized against non-heated sample $(\mathrm{NH})$ considered to have $100 \%$ of reactivity.
A

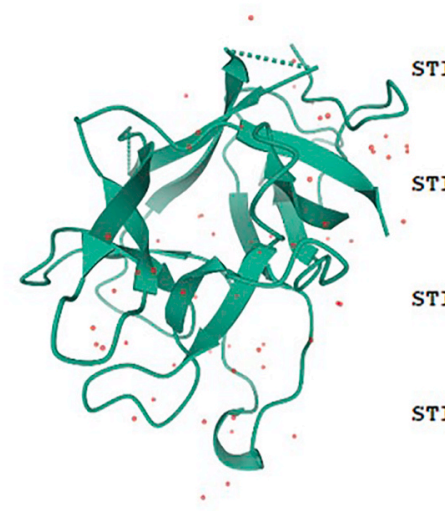

B

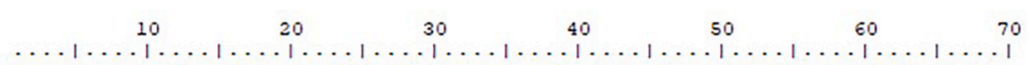

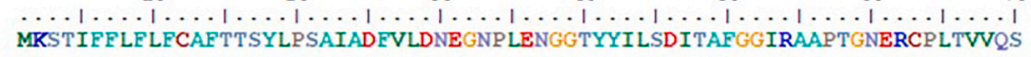

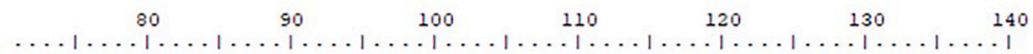
RNELDKGIGTIISSPYRIREIAEGHPLSLREDSAVIMLCVGIPTEWSVVEDLPEGPAVKI GENRDAMDG

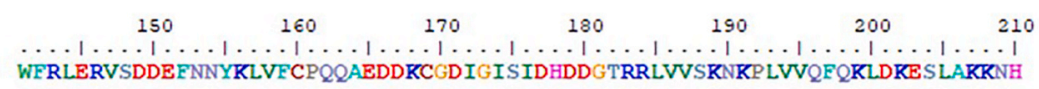
GLSRSE

Fig. 5. Conformational (A) and primary (B) sequences of soybean trypsin inhibitor (Gly m TI) (PDB accession number 1BA7) (https://www.rcsb.org/). 


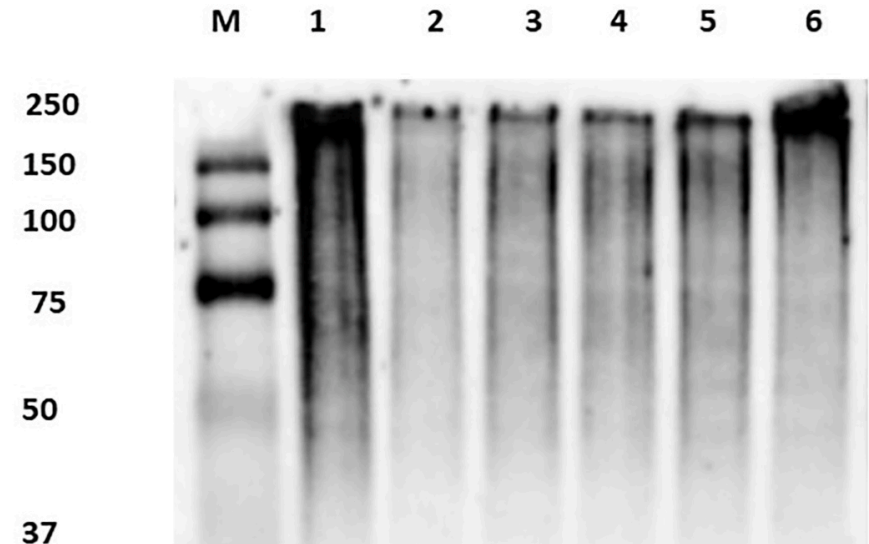

37

25

20

15

10
Recently, published literature has highlighted the impact of moderate electric fields and frequency on the immunoreactivity of whey protein fractions, conformation and structural alterations in protein such as $\beta$-lactoglobulin, BSA, lysozyme, as well as on the activation/deactivation of biological entities such as enzymes (Bekard and Dunstan, 2014; Pereira et al., 2020; Rodrigues et al., 2020; Samaranayake and Sastry, 2016, Samaranayake and Sastry, 2018). The effects in protein structure, resultant of electric fields applied in $\mathrm{OH}$ have been increasingly reported and their mechanisms start to be understood. The polarity changes associated with the electric field alternation causes dipole orientation, internal friction and rotations, thus destabilizing the conformational structure of proteins'. These actions were demonstrated to be potentiated by the increase of the EF intensity and were more effective under low frequencies, as observed in this study. Apart from the electric field intensity and frequency, external factors like $\mathrm{pH}$, ionic strength, temperature, or protein type, also seem to play important roles in the reported effects. Furthermore, based on the outcomes of this study, the electrochemical reactions should not be overlooked, particularly at a low frequency regime $(<500 \mathrm{~Hz})$, in the presence of protein fractions with high affinity to metals (e.g., Fe), since it may result in the development of complexes and changes in the IgG-binding capacity. Thermal effects on the immunoreactivity of proteins are still controversial and information about the influence of $\mathrm{OH}$ electrical variables in this regard is inexistent. These results confirm that $\mathrm{OH}$, despite being a thermal process in nature, should not be compared to conventional heating, also offering the opportunity to modulate immunoreactivity of SPI through the control of the applied electrical conditions, namely electric frequency and field.

\section{Conclusions}

$\mathrm{OH}$ applied at frequencies between 50 and $500 \mathrm{~Hz}$ can promote conformational disturbances on soybean protein fractions, traduced by a quenching effect of fluorescence emission of the aromatic amino acids. This quenching effect can be intrinsically related to the occurrence of complexation reactions with metal leaked to the protein solution during $\mathrm{OH}$, though there is scarce information about the impact of electrical variables, as electric field and frequency, on soybean protein fractions. Similarly, to what happens with $\beta$-lactoglobulin, more knowledge is required on the electrical effects promoted by $\mathrm{OH}$ towards structures, conformations, and protein-protein interactions of soybean proteins. This knowledge is even more important when considering that, in addition to the thermal effect, the presence of electric fields at $50 \mathrm{~Hz}$ also causes significant reductions of the immunoreactivity of Gly $\mathrm{m}$ TI allergen, as confirmed by ELISA and immunoblotting testing, which might be extended to other soybean allergenic proteins. Still, this extrapolation needs further confirmation, since it is known that the same processing treatment might induce distinct effects on the allergenicity of different proteins. Moreover, it would be important to understand if this immunoreactivity reduction is linked to electrochemical reactions or eventual conformational or aggregation protein patterns imposed by $\mathrm{OH}$. Interactions between protein and metals during $\mathrm{OH}$ can provide opportunities if properly controlled, but they can also arise safety concerns that need to be considered.

Results from this work underline the importance of controlling $\mathrm{OH}$ processing parameters, presenting valuable information about the impact of this electroheating technology on the soybean processing industry. The mitigation of soybean immunoreactivity is of utmost importance, particularly because soybean proteins are currently regarded as excellent alternatives to animal proteins. Understanding the effects of the metal released during $\mathrm{OH}$, as well as their possible synergic implications in food quality and safety attributes must be considered on the design and implementation of $\mathrm{OH}$ at industrial plants. 


\section{CRediT authorship contribution statement}

Ricardo N. Pereira: Conceptualization, Writing - original draft, Writing - review \& editing, Supervision, Project administration. Rui M. Rodrigues: Conceptualization, Writing - original draft, Writing - review \& editing, Supervision. Luís Machado: Investigation, Writing original draft. Sara Ferreira: Investigation, Writing - original draft. Joana Costa: Writing - review \& editing, Supervision, Project administration. Caterina Villa: Investigation, Writing - original draft. Mariana P. Barreiros: Writing - review \& editing, Resources. Isabel Mafra: Writing - review \& editing, Supervision, Project administration, Funding acquisition. José A. Teixeira: Writing - review \& editing, Resources. António A. Vicente: Writing - review \& editing, Resources.

\section{Declaration of competing interest}

There are no conflicts to declare.

\section{Acknowledgements}

This study was supported by the Portuguese Foundation for Science and Technology (FCT) under the scope of the strategic funding of UIDB/ 04469/2020 and UID/QUI/50006/2020 with funding from FCT/MCTES through national funds, and AgriFood XXI R\&D\&I project, operation number NORTE-01-0145-FEDER-000041 and NORTE-01-0145-FEDER000052, co-financed by the European Regional Development Fund (FEDER) through NORTE 2020 (Northern Regional Operational Program 2014/2020). This work also received financial support from the European Union (FEDER funds through COMPETE POCI-01-0145FEDER-031720) and National Funds (FCT) through project AlleRiskAssess PTDC/BAA-AGR/31720/2017. Caterina Villa and Luís Machado thank FCT for their grants under project AlleRiskAssess (PTDC/BAA-AGR/31720/2017). Joana Costa thanks FCT for funding through program DL 57/2016 - Norma transitória (SFRH/BPD/102404/ 2014). Ricardo N. Pereira acknowledge FCT for its Assistant Research contract obtained under CEEC Individual 2017.

\section{References}

Allergome. (2020). http://www.allergome.org./.

Arii, Y., \& Takenaka, Y. (2014). Initiation of protein association in tofu formation by metal ions. Bioscience Biotechnology \& Biochemistry, 78(1), 86-91. https://doi.org/ 10.1080/09168451.2014.877341

Ashaolu, T. J. (2020). Health applications of soy protein hydrolysates. International Journal of Peptide Research and Therapeutics, 26(4), 2333-2343. https://doi.org/ 10.1007/s10989-020-10018-6

Assiry, A. M., Sastry, S. K., \& Samaranayake, C. P. (2006). Influence of temperature, electrical conductivity, power and $\mathrm{pH}$ on ascorbic acid degradation kinetics during ohmic heating using stainless steel electrodes. Bioelectrochemistry, 68(1), 7-13. https://doi.org/10.1016/j.bioelechem.2005.02.005

Atapour, M., Odnevall Wallinder, I., \& Hedberg, Y. (2020). Stainless steel in simulated milk and whey protein solutions - influence of grade on corrosion and metal release. Electrochimica Acta, 331, 135428. https://doi.org/10.1016/j.electacta.2019.135428

Atapour, M., Wei, Z., Chaudhary, H., Lendel, C., Odnevall Wallinder, I., \& Hedberg, Y. (2019). Metal release from stainless steel $316 \mathrm{~L}$ in whey protein - and simulated milk solutions under static and stirring conditions. Food Control, 101, 163-172. https:// doi.org/10.1016/j.foodcont.2019.02.031

Bekard, I., \& Dunstan, D. E. (2014). Electric field induced changes in protein conformation. Soft Matter, 10(3), 431-437. https://doi.org/10.1039/c3sm52653d

Biter, A. B., Pollet, J., Chen, W.-H., Strych, U., Hotez, P. J., \& Bottazzi, M. E. (2019). A method to probe protein structure from UV absorbance spectra. Analytical Biochemistry, 587, 113450. https://doi.org/10.1016/j.ab.2019.113450

Cabanillas, B., Cuadrado, C., Rodriguez, J., Dieguez, M. C., Crespo, J. F., \& Novak, N. (2018). Boiling and pressure cooking impact on IgE reactivity of soybean allergens. International Archives of Allergy and Immunology, 175(1-2), 36-43. https://doi.org/ 10.1159/000485894

Chen, N., Zhao, M., Chassenieux, C., \& Nicolai, T. (2016). Structure of self-assembled native soy globulin in aqueous solution as a function of the concentration and the pH. Food Hydrocolloids, 56, 417-424. https://doi.org/10.1016/j. foodhyd.2015.12.028

Costa, J., Bavaro, S. L., Benedé, S., Diaz-Perales, A., Bueno-Diaz, C., Gelencser, E., Klueber, J., Larré, C., Lozano-Ojalvo, D., Lupi, R., Mafra, I., Mazzucchelli, G., Molina, E., Monaci, L., Martín-Pedraza, L., Piras, C., Rodrigues, P. M., Roncada, P., Schrama, D., ... Holzhauser, T. (2020). Are physicochemical properties shaping the allergenic potency of plant allergens? Clinical Reviews in Allergy and Immunology. https://doi.org/10.1007/s12016-020-08810-9

De Meester, P., Brick, P., Lloyd, L. F., Blow, D. M., \& Onesti, S. (1998). Structure of the Kunitz-type soybean trypsin inhibitor (STI): Implication for the interactions between members of the STI family and tissue-plasminogen activator. Acta Crystallographica Section D Biological Crystallography, 54(4), 589-597. https://doi.org/10.1107/ S0907444997015849

Deng, X.-X., Zhang, N., \& Tang, C.-H. (2017). Soy protein isolate as a nanocarrier for enhanced water dispersibility, stability and bioaccessibility of $\beta$-carotene. Journal of the Science of Food and Agriculture, 97(7), 2230-2237. https://doi.org/10.1002/ jsfa. 8033

Dong, S. Z., Chen, C. Z., Li, D. M., \& Sun, Y. S. (1993). [A study of hygienic standard for titanium in the source of drinking water]. Zhonghua Yu Fang Yi Xue Za Zhi, 27(1), 26-28 [Chinese journal of preventive medicine] http://europepmc.org/abstract/ME D/8325174.

Geada, P., Rodrigues, R. M., Loureiro, L., Pereira, R. N., Fernandes, B., Teixeira, J. A. J. A., Vasconcelos, V., \& Vicente, A. A. A. (2018). Electrotechnologies applied to microalgal biotechnology - applications, techniques and future trends. Renewable and Sustainable Energy Reviews, 94, 656-668. https://doi.org/10.1016/j. rser.2018.06.059

Hsia, S.-Y., Hsiao, Y.-H., Li, W.-T., \& Hsieh, J.-F. (2016). Aggregation of soy proteinisoflavone complexes and gel formation induced by glucono- $\delta$-lactone in soymilk. Scientific Reports, 6(1), 35718. https://doi.org/10.1038/srep35718

Huang, L., Zhang, W., Ding, X., Wu, Z., \& Li, Y. (2020). Effects of dual-frequency ultrasound with different energy irradiation modes on the structural and emulsifying properties of soy protein isolate. Food and Bioproducts Processing, 123, 419-426. https://doi.org/10.1016/j.fbp.2020.07.021

Jiang, J., Wang, Q., \& Xiong, Y. L. (2018). A pH shift approach to the improvement of interfacial properties of plant seed proteins. Current Opinion in Food Science, 19, 50-56. https://doi.org/10.1016/j.cofs.2018.01.002

Jiang, J., Xiong, Y. L., \& Chen, J. (2010). pH shifting alters solubility characteristics and thermal stability of soy protein isolate and its globulin fractions in different $\mathrm{pH}$, salt concentration, and temperature conditions. Journal of Agricultural and Food Chemistry, 58(13), 8035-8042. https://doi.org/10.1021/jf101045b

Li, Y., Chen, Z., \& Mo, H. (2007). Effects of pulsed electric fields on physicochemical properties of soybean protein isolates. Lebensmittel-Wissenschaft und -TechnologieFood Science and Technology, 40(7), 1167-1175. https://doi.org/10.1016/j. lwt.2006.08.015

Liu, H., Bao, X. L., Lv, Y., Xu, J. T., \& Guo, S. T. (2012). Separation and evaluation of soybean protein hydrolysates prepared by immobilized metal ion affinity chromatography with different metal ions. Journal of Chromatographic Science, 50(8), 714-720. https://doi.org/10.1093/chromsci/bms071

Liu, Z. S., Chang, S. K. C., Li, L. T., \& Tatsumi, E. (2004). Effect of selective thermal denaturation of soybean proteins on soymilk viscosity and tofu's physical properties. Food Research International, 37(8), 815-822. https://doi.org/10.1016/j. foodres.2004.04.004

Liu, Y., Yang, J., Lei, L., Wang, L., Wang, X., Ying Ma, K., Yang, X., \& Chen, Z.-Y. (2017). $7 \mathrm{~S}$ protein is more effective than total soybean protein isolate in reducing plasma cholesterol. Journal of Functional Foods, 36, 18-26. https://doi.org/10.1016/j. jff.2017.06.039

Li, X., Ye, C., Tian, Y., Pan, S., \& Wang, L. (2018). Effect of ohmic heating on fundamental properties of protein in soybean milk. Journal of Food Process Engineering, 41(3), 1-10. https://doi.org/10.1111/jfpe.12660

Lu, L., Zhao, L., Zhang, C., Kong, X., Hua, Y., \& Chen, Y. (2015). Comparative effects of ohmic, induction cooker, and electric stove heating on soymilk trypsin inhibitor inactivation. Journal of Food Science, 80(3), C495-C503. https://doi.org/10.1111/ 1750-3841.12773

Meinlschmidt, P., Ueberham, E., Lehmann, J., Reineke, K., Schlüter, O., SchweiggertWeisz, U., \& Eisner, P. (2016). The effects of pulsed ultraviolet light, cold atmospheric pressure plasma, and gamma-irradiation on the immunoreactivity of soy protein isolate. Innovative Food Science \& Emerging Technologies, 38, 374-383. https://doi.org/10.1016/j.ifset.2016.06.007

Monteiro, S. R., \& Lopes-da-Silva, J. A. (2019). Critical evaluation of the functionality of soy protein isolates obtained from different raw materials. European Food Research and Technology, 245(1), 199-212. https://doi.org/10.1007/s00217-018-3153-X

O’Neill, T. E., \& Kinsella, J. E. (1987). Flavor protein interactions: Characteristics of 2nonanone binding to isolated soy protein fractions. Journal of Food Science, 52(1), 98-101. https://doi.org/10.1111/j.1365-2621.1987.tb13980.x

Pataro, G., Barca, G. M. J., Pereira, R. N., Vicente, A. A. A., Teixeira, J.a. J. A., \& Ferrari, G. (2014). Quantification of metal release from stainless steel electrodes during conventional and pulsed ohmic heating. Innovative Food Science \& Emerging Technologies, 21, 66-73. https://doi.org/10.1016/j.ifset.2013.11.009. G. M. J.

Peng, H.-L., \& Callender, R. (2018). Mechanism for fluorescence quenching of tryptophan by oxamate and pyruvate: Conjugation and solvation-induced photoinduced electron transfer. Journal of Physical Chemistry B, 122(25), 6483-6490. https://doi.org/ 10.1021/acs.jpcb.8b02433

Pereira, R. N., Costa, J., Rodrigues, R. M., Villa, C., Machado, L., Mafra, I., \& Vicente, A. (2020). Effects of ohmic heating on the immunoreactivity of $\beta$-lactoglobulin - a relationship towards structural aspects. Food \& Function. https://doi.org/10.1039/ c9fo02834j

Pereira, R. N., Rodrigues, R. M., Altinok, E., Ramos, Ó. L., Xavier Malcata, F., Maresca, P., Ferrari, G., Teixeira, J. A., \& Vicente, A. A. (2017). Development of iron-rich whey protein hydrogels following application of ohmic heating - effects of moderate electric fields. Food Research International, 99(Pt 1), 435-443. https://doi.org/ 10.1016/j.foodres.2017.05.023 
Pereira, R. N., Rodrigues, R. M., Ramos, Ó. L., Xavier Malcata, F., Teixeira, J. A., \& Vicente, A. A. (2016). Production of whey protein-based aggregates under ohmic heating. Food and Bioprocess Technology, 9(4). https://doi.org/10.1007/s11947-015 1651-4

Porath, J., Carlsson, J., Olsson, I., \& Belfrage, G. (1975). Metal chelate affinity chromatography, a new approach to protein fractionation. Nature, 258(5536), 598-599. https://doi.org/10.1038/258598a0

Quirce, S., Fernández-Nieto, M., Polo, F., \& Sastre, J. (2002). Soybean trypsin inhibitor is an occupational inhalant allergen. The Journal of Allergy and Clinical Immunology, 109 (1), 178. https://doi.org/10.1067/mai.2002.120952

Remondetto, G. E., Paquin, P., \& Subirade, M. (2002). Cold gelation of $\beta$-lactoglobulin in the presence of iron. Journal of Food Science, 67(2), 586-595. https://doi.org/ 10.1111/j.1365-2621.2002.tb10643.x

Rickert, D. A., Johnson, L. A., \& Murphy, P. A. (2004). Functional properties of improved glycinin and $\beta$-conglycinin fractions. Journal of Food Science, 69(4). https://doi.org/ 10.1111/j.1365-2621.2004.tb06332.x

Rodrigues, R. M., Avelar, Z., Vicente, A. A., Petersen, S. B., \& Pereira, R. N. (2020). Influence of moderate electric fields in $\beta$-lactoglobulin thermal unfolding and interactions. Food Chemistry, 304. https://doi.org/10.1016/j. foodchem.2019.125442. March 2019.

Roychaudhuri, R., Sarath, G., Zeece, M., \& Markwell, J. (2003). Reversible denaturation of the soybean Kunitz trypsin inhibitor. Archives of Biochemistry and Biophysics, 412 (1), 20-26. https://doi.org/10.1016/S0003-9861(03)00011-0

Roychaudhuri, R., Sarath, G., Zeece, M., \& Markwell, J. (2004). Stability of the allergenic soybean Kunitz trypsin inhibitor. Biochimica et Biophysica Acta (BBA) - Proteins \& Proteomics, 1699(1), 207-212. https://doi.org/10.1016/j.bbapap.2004.02.014

Salari, S., \& Jafari, S. M. (2020). The influence of ohmic heating on degradation of food bioactive ingredients. Food Engineering Reviews, 12(2), 191-208. https://doi.org/ 10.1007/s12393-020-09217-0

Samaranayake, C. P., \& Sastry, S. K. (2016). Effects of controlled-frequency moderate electric fields on pectin methylesterase and polygalacturonase activities in tomato homogenate. Food Chemistry, 199(Supplement C), 265-272. https://doi.org/ 10.1016/j.foodchem.2015.12.010

Samaranayake, C. P., \& Sastry, S. K. (2018). In-situ activity of $\alpha$-amylase in the presence of controlled-frequency moderate electric fields. Lebensmittel-Wissenschaft und -Technologie- Food Science and Technology, 90, 448-454. https://doi.org/10.1016/j. lwt.2017.12.053
Sastry, S. K. (2004). Advances in ohmic heating and moderate electric field (MEF) processing. In Novel food processing technologies (pp. 491-499). https://doi.org/ 10.1201/9780203997277.ch23

Schmid, F.-X. (2001). Biological macromolecules: UV-visible spectrophotometry. In In eLS. https://doi.org/10.1038/npg.els.0003142

Sobral, P. A., Palazolo, G. G., \& Wagner, J. R. (2010). Thermal behavior of soy protein fractions depending on their preparation methods, individual interactions, and storage conditions. Journal of Agricultural and Food Chemistry, 58(18), 10092-10100. https://doi.org/10.1021/jf101957f

Verhoeckx, K. C. M., Vissers, Y. M., Baumert, J. L., Faludi, R., Feys, M., Flanagan, S., Herouet-Guicheney, C., Holzhauser, T., Shimojo, R., van der Bolt, N., Wichers, H., \& Kimber, I. (2015). Food processing and allergenicity. Food and Chemical Toxicology, 80, 223-240. https://doi.org/10.1016/j.fct.2015.03.005

Villa, C., Moura, M. B. M. V., Costa, J., \& Mafra, I. (2020). Immunoreactivity of lupine and soybean allergens in foods as affected by thermal processing. In, Vol. 9. Foods. https://doi.org/10.3390/foods9030254, 3.

Wang, J., Na, X., Navicha, W. B., Wen, C., Ma, W., Xu, X., Wu, C., \& Du, M. (2020). Concentration-dependent improvement of gelling ability of soy proteins by preheating or ultrasound treatment. Lebensmittel-Wissenschaft \& Technologie, 134, 110170. https://doi.org/10.1016/j.lwt.2020.110170

WHO/IUIS Allergen Nomenclature Home Page. (2020). Cited 2018 May 9 http://www. allergen.org/.

Wu, C., Ma, W., \& Hua, Y. (2019). The relationship between breaking force and hydrophobic interactions or disulfide bonds involved in heat-induced soy protein gels as affected by heating time and temperature. International Journal of Food Science and Technology, 54(1), 231-239. https://doi.org/10.1111/ijfs.13931

Yildiz, G., Andrade, J., Engeseth, N. E., \& Feng, H. (2017). Functionalizing soy protein nano-aggregates with pH-shifting and mano-thermo-sonication. Journal of Colloid and Interface Science, 505, 836-846. https://doi.org/10.1016/j.jcis.2017.06.088

Zhang, H., Li, L., Tatsumi, E., \& Isobe, S. (2005). High-pressure treatment effects on proteins in soy milk. Lebensmittel-Wissenschaft und-Technologie- Food Science and Technology, 38(1), 7-14. https://doi.org/10.1016/j.lwt.2004.04.007

Zhang, Y., Niu, F., Zhang, X., Lu, Z., Guo, Y., \& Wang, H. (2018). Controlled enzymatic hydrolysis on characteristic and antioxidant properties of soybean protein isolatemaltodextrin conjugates. International Journal of Food Properties, 21(1), 2239-2249. https://doi.org/10.1080/10942912.2018.1508154 